\title{
End-product Control of Acetohydroxyacid Synthetase by Valine in Penicillium chrysogenum Q176 and a High Penicillin-yielding Mutant
}

\author{
By S. A. GOULDEN \\ Glaxo Laboratories Ltd., Ulverston, Lancashire \\ AND F. W. CHATTAWAY \\ Department of Biochemistry, University of Leeds, Leeds 2
}

(Accepted for publication II August 1969)

\begin{abstract}
SUMMARY
Acetohydroxyacid synthetase produced by Penicillium chrysogenum Q I76 and a high penicillin-producing mutant have been compared. Both were sensitive to valine as the major feedback inhibitor. Inhibition of the enzyme in Q 176 appears to be effected through two valine binding sites, but only one of these remains in the high yielding strain and it is non-competitive with respect to pyruvate. The amount of enzyme activity detectable in the high yielding strain is more than twice the level in Q I 76. Control of acetohydroxyacid synthetase by other related amino acids was shown to be complex and involved sites other than the valine binding site.
\end{abstract}

\section{INTRODUCTION}

The formation of large quantities of penicillin by some strains of Penicillium chrysogenum creates a demand for its component amino acids far in excess of the demands of protein synthesis normally experienced by micro-organisms. The correlation between ability to take up sulphate and penicillin production potential in a number of strains, observed by Tardrew \& Johnson (I958) and by Segel \& Johnson (I96I), is probably associated with the way these strains satisfy their high requirements for cysteine.

The biosynthetic reactions leading to the formation of the homologous amino acids valine and isoleucine, have been shown to be catalysed by a single set of enzymes in all organisms studied (for review see Umbarger \& Davis, I962). To facilitate metabolic control over the production of these amino acids (and of leucine derived from the precursor of valine) a variety of end-product control mechanisms has developed in different organisms. In a number of Enterobacteria end-product control is achieved by both enzyme repression and feed-back inhibition (Umbarger \& Brown, 1957; Leavitt \& Umbarger, I96I ; Freundlich, Burns \& Umbarger, 1962; and Armstrong \& Wagner, I963). Only valine has been found to be an effective inhibitor of acetohydroxyacid synthetase, the first enzyme in the sequence of reactions leading to the formation of valine, whereas all three amino acids, together with pantothenate and threonine (the source of isoleucine) are required to exert maximum enzyme repression. In Saccharomyces cerevisiae, Magee \& de Robichon-Szulmajster (I968) have shown 
feedback inhibition to be exerted by valine on acetohydroxyacid synthetase. Other related amino acids had little effect.

Our work shows that although the potential to produce penicillin has been increased at least five times in the production of the tested high yielding strain from Penicillium chrysogenum Q 176 (a low penicillin producing strain) feedback inhibition of acetohydroxyacid synthetase still exists, although the enzyme is less sensitive to valine. The high yielding strain was also found to produce more enzyme than the strain from which it was derived.

\section{METHODS}

Preparation of mycelium. Spores of Penicillium chrysogenum Q I 76 (CMI 37767) and a high penicillin producing mutant derived from it by u.v. irradiation were produced in a liquid medium containing brown sugar, $2 \% ; \mathrm{NaNO}_{3}, 0.6 \%, \mathrm{KH}_{2} \mathrm{PO}_{4}, 0.15 \%$; $\mathrm{MgSO}_{4} .7 \mathrm{H}_{2} \mathrm{O}, 0.05 \%$; and $\mathrm{CaCl}_{2}, 2.5 \%$-adjusted to $\mathrm{pH} 6.5$. First stage shaken cultures of mycelium were produced from these spores on the following growth

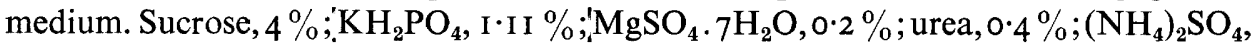
$0.44 \% ; \mathrm{CaCO}_{3}, 0.5 \% ; \mathrm{FeSO}_{4} .7 \mathrm{H}_{2} \mathrm{O}, 0.0025 \% ; \mathrm{MnSO}_{4} .4 \mathrm{H}_{2} \mathrm{O}_{4}, 0.0025 \%$; $\mathrm{ZnSO}_{4} \cdot 7 \mathrm{H}_{2} \mathrm{O}, 0.0025 \% ; \mathrm{CuSO}_{4} \cdot 5 \mathrm{H}_{2} \mathrm{O}, 0.0025 \%$.

Second stage growth cultures using the growth medium were inoculated with a $25 \%(\mathrm{v} / \mathrm{v})$ inoculum from the first stage culture after $48 \mathrm{hr}$ growth. Mycelium taken from this second stage after $18 \mathrm{hr}$ was more consistent in growth and enzyme properties than mycelium from the first growth stage and was used for all experiments reported here. Mycelium was washed three times by slurry and refiltration in 0.1 M-sucrosephosphate buffer, $\mathrm{pH} 7 \cdot 0$, and pressed dry between filter papers. Dry weights were determined by drying under reduced pressure at $55^{\circ}$ for $\mathrm{I} 8 \mathrm{hr}$.

Enzyme preparation. (a) Benzene treated cells. The mycelium was made permeable by a modification of the technique of Magee \& de Robichon-Szulmajster (I968). Pressed dry mycelium (I g.) was suspended in $25 \%$ (v/v) glycerol $(25 \mathrm{ml}$. containing

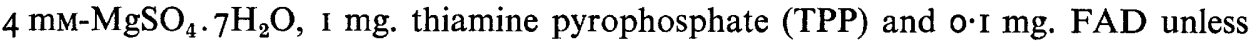
otherwise stated) and treated with $10 \%(\mathrm{v} / \mathrm{v})$ benzene on a Whirlimixer for $30 \mathrm{sec}$. This suspension was used directly.

(b) Cell-free extracts. These were produced by grinding pressed dry mycelium in an ice cold mortar and pestle with $\mathrm{I} \frac{1}{2}$ times its own wt of glass beads ( $3 \mathrm{M}$ superbrite, $200 \mu$ ) in $\mathrm{I} \frac{1}{2}$ times its own wt of the $25 \%(\mathrm{v} / \mathrm{v})$ glycerol cofactor solution mentioned above. After grinding the preparation was taken up in glycerol cofactor solution to be equivalent to I g. mycelium in $25 \mathrm{ml}$. (as used in the benzene treated cells) and the cell debris removed by gentle filtration through glass wool. The filtrate was used immediately.

Enzyme assay. The assay for acetohydroxyacid synthetase was similar to the one described by Magee \& de Robichon-Szulmajster (I968). The incubation mixture contained $0.5 \mathrm{ml} .0 .2 \mathrm{M} \cdot \mathrm{KH}_{2} \mathrm{PO}_{4}$ buffer brought to the required $\mathrm{pH}$, normally $\mathrm{pH} 7 \cdot 3$, with $\mathrm{M}$-tris solution, and $0.5 \mathrm{ml}$. sodium pyruvate at the required strength. The total incubation volume, including $0.5 \mathrm{ml}$. enzyme suspension, was brought to $2 \mathrm{ml}$. with $25 \%(\mathrm{v} / \mathrm{v})$ glycerol. In inhibition experiments, inhibitor was added at the required concentration in the buffer. The duration of the incubation was normally $30 \mathrm{~min}$. at room temperature $\left(22\right.$ to $23^{\circ}$ ) although some incubations with QI76, and those with cell free extracts were continued for $60 \mathrm{~min}$. 
Acetolactate formation was determined by converting it to acetoin by acid decarboxylation and by assaying the acetoin by the method of Westerfeld (I945). This method is only valid if no acetoin is produced directly from pyruvate by the organism. Juni (I96I) showed that acetoin was produced solely from pyruvate in Saccharomyces cerevisiae, without decarboxylation of acetolactate. This we showed to be the case in Penicillium chrysogenum (although the amounts of acetoin formed were small and variable), allowing the assay of acetolactate formation by the difference between acetoin formation with and without acid decarboxylation, as did Magee \& de RobichonSzulmajster (1968) in their study of S. cerevisiae.

Optical densities were measured in a Unicam SP 500 or an Eel Spectra and read off against calibration curves produced with ether washed acetoin. The difference in colour yield between acid and alkaline assays reported by Magee \& de RobichonSzulmajster (1968) was confirmed.

Chemicals. Sodium acetolactate was synthesized by the method of Krampitz (1948). The ester, methyl acetoxyethylacetoacetate, was hydrolysed immediately before use and the mixture used without purification. FAD and TPP were obtained from Sigma (London) Ltd. Other chemicals were from BDH (Chemicals) Ltd.

\section{RESULTS}

\section{Optimal pH and co-factor requirements}

Optimal $\mathrm{pH}$ conditions and co-factor requirements were determined using the high yielding strain of Penicillium chrysogenum. Although crude cell-free extracts showed

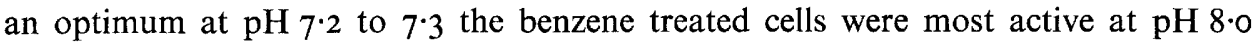
(Fig. I). No explanation for this difference has been found and all subsequent incuba-

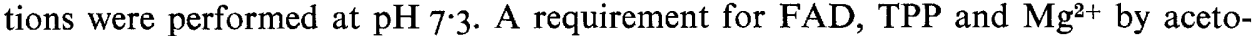
hydroxyacid synthetase had been demonstrated in a number of organisms (Umbarger \& Davis, I962). All three were found necessary for achieving maximum activity in Penicillium chrysogenum (Table I). They were also found necessary for enzyme stability;

Table I. Co-factor requirements for acetolactate formation

\begin{tabular}{ccccc} 
& \multicolumn{4}{c}{ Co-factors present } \\
\cline { 2 - 4 } & FPP $\mathrm{Mg}^{2+}$ & TPP & $\mathrm{Mg}^{2+}$ & TPP \\
Acetolactate formation ( $\%)$ & I00 & FAD & FAD & $\mathrm{Mg}^{2+}$ \\
& 59 & 42 & 69
\end{tabular}

Cells of high yielding strain rendered permeable in the absence of co-factors. Co-factors added as stated immediately before incubation. Incubated for I $5 \mathrm{~min}$. Results expressed as percentage of acetolactate produced in the presence of all co-factors.

when they were added after benzene treatment, $30 \%$ of the activity was lost in $2 \mathrm{hr}$, but when added prior to benzene treatment the enzyme remained fully active for at least $45 \mathrm{~min}$. However the sensitivity to valine seemed to increase on standing after benzene treatment. No satisfactory explanation for this observation has been found.

\section{Kinetics of acetolactate formation}

All kinetic data were determined on benzene treated cells. These gave consistent results with the two strains, and from Lineweaver-Burk plots (Fig. 2) the $K_{m}(p y r)$ 
was found to be between $I \cdot I$ and $I \cdot 7 \times 10^{-2}$ for both strains. However, Q I 76 consistently produced less enzyme activity than the high yielding strain as can be seen in Fig. 2 ; the $V_{\max }$ for Q176 was found to be $23 \mu$ moles acetolactate $/ \mathrm{hr} / \mathrm{mg}$. dry wt, whereas from the high yielding strain it reached $56 \mu$ moles acetolactate $/ \mathrm{hr} / \mathrm{mg}$. dry wt

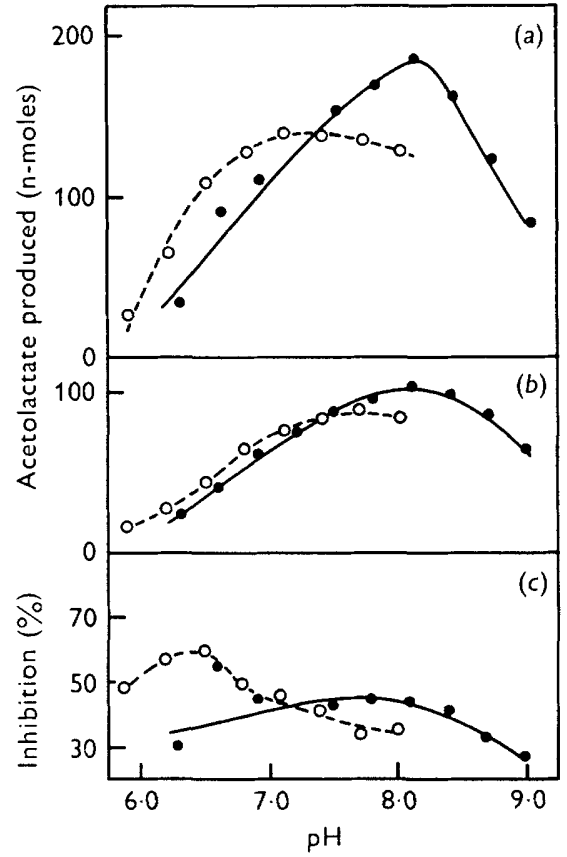

Fig. I

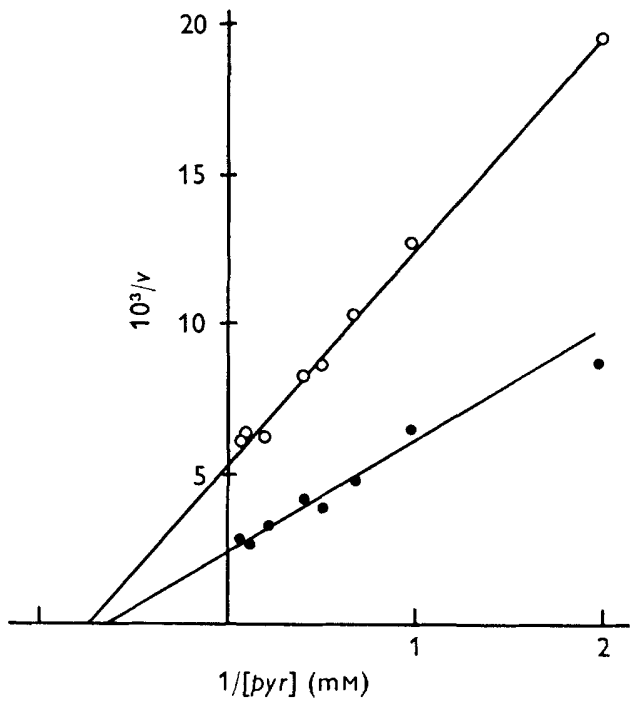

Fig. 2

Fig. I. Effect of $\mathrm{pH}$ on acetohydroxyacid synthetase. Enzyme from high yielding strain either benzene treated $(\Theta)$ and incubated for $30 \mathrm{~min}$. or extracted by grinding $(O)$ and incubated for $60 \mathrm{~min}$. Co-factors added prior to above treatment. Substrate concentration $50 \mathrm{mM}$. In the absence $(a)$, in the presence $(b)$ of $35 \mu_{\mathrm{M}} \mathrm{L}$-valine. Percentage inhibition of enzyme activity $(c)$.

Fig. 2. $K_{m}(p y r)$ of acetohydroxyacid synthetase in benzene treated cells. Q I76, ○- ; high yielding strain,

\section{Inhibition of acetohydroxyacid synthetase}

Valine was found to be an extremely effective inhibitor of the enzyme in both strains. A comparison of its activity with that of other amino acids was made using the high yielding strain. Valine $(35 \mu \mathrm{M})$ caused more inhibition than $10 \mathrm{~mm}$ concentrations of the other amino acids (Fig. 3). Of those tested, only isoleucine exerted a greater effect with increasing concentration. Inhibition by leucine or threonine alone was similar to that caused by a metabolically unrelated amino acid, histidine, and was probably an unspecific effect. Inhibition by mixtures of amino acids generally gave inhibition effects equal to the sum of their individual effects (Fig. 4), although mixtures containing threonine showed less inhibition than would have been expected by addition of their individual effects.

Kinetics of inhibition. Lineweaver-Burk plots in the presence and absence of $35 \mu \mathrm{M}$ valine suggested the inhibition of acetohydroxyacid synthetase to be non-competitive 


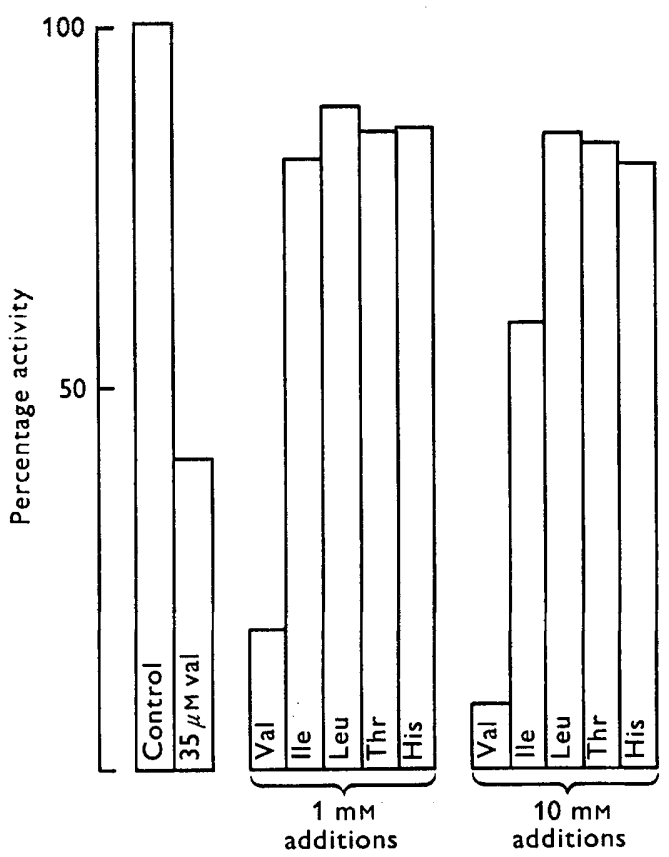

Fig. 3

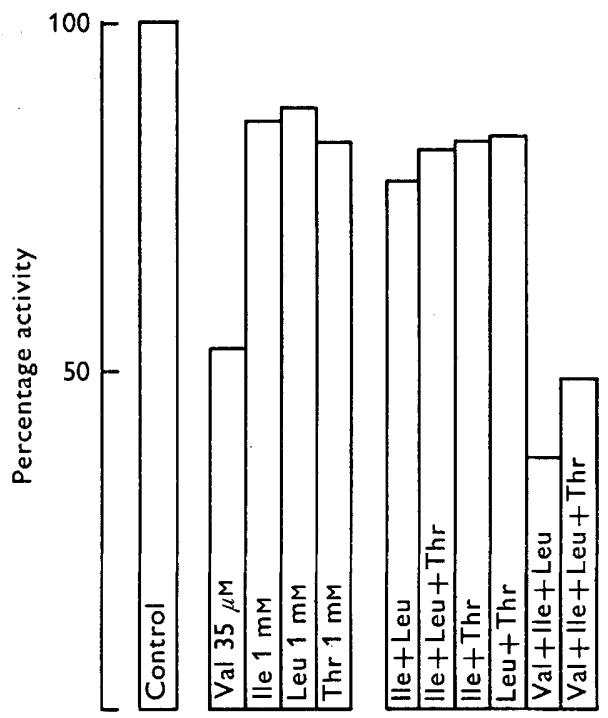

Fig. 4

Fig. 3. Inhibition of acetohydroxyacid synthetase by various amino acids. Benzene treated cells of high yielding strain were used. Pyruvate concentration, $50 \mathrm{~mm}$. Amino acids were added at stated concentrations after benzene treatment.

Fig. 4. Inhibition of acetohydroxyacid synthetase by mixtures of amino acids. Benzene treated cells of high yielding strain were used. Pyruvate concentration, $50 \mathrm{~mm}$. Amino acids were added at stated concentrations after benzene treatment.
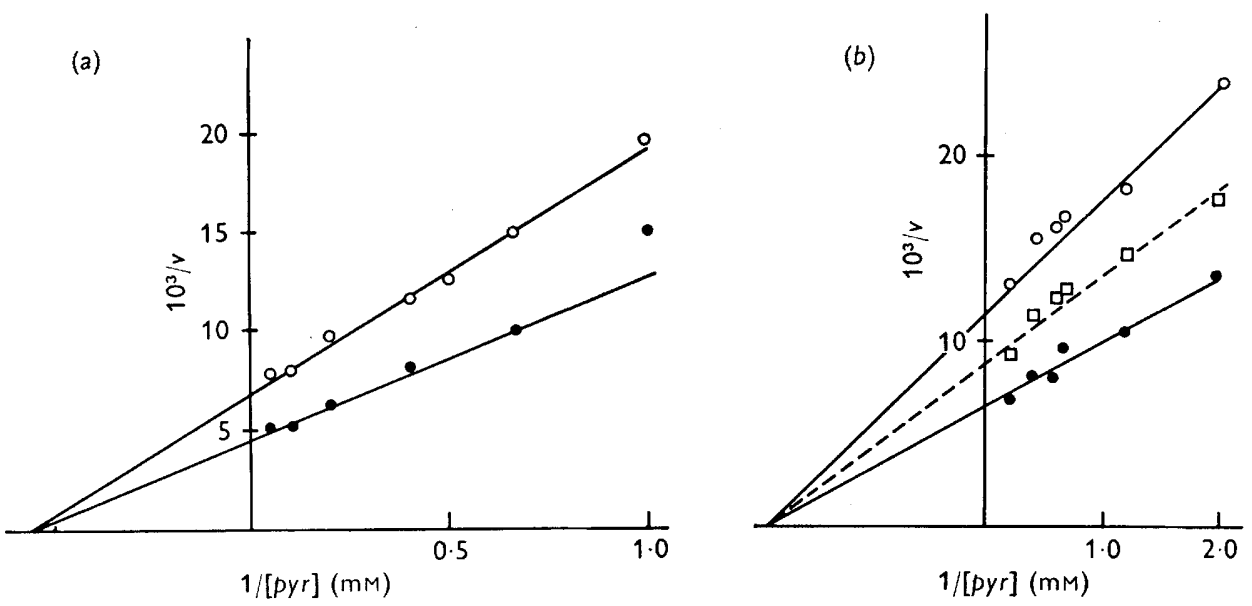

Fig. 5. Lineweaver-Burk plots of activity of acetohydroxyacid synthetase in absence and presence of $35 \mu \mathrm{M}$ L-valine. Benzene-treated cells were used. Strain Q I 76 (a); high-yielding strain $(b)$. No valine added $(\bullet)$; valine added ( $35 \mu \mathrm{M},(O)$; isoleucine added (Io $\mathrm{mM}),(\square)$. 
with respect to pyruvate in both strains (Fig. $5 a, b$ ). Such inhibition results were obtained at both $\mathrm{pH} 7 \cdot 3$ and $8 \cdot 0$, with benzene treated cells and with cell-free extracts.

Inhibition kinetics of the enzyme from Q I76, however, were typical of an enzyme with two inhibitor binding sites. At low substrate concentrations, a plot of the reciprocal of the activity against increasing inhibitor concentration gave a curve of increasing inhibition whereas at saturating substrate concentrations an identical plot gave a linear increase (Fig. $6 a$ ). The high yielding strain gave reciprocal plots corresponding to an enzyme with one non-competitive inhibitor binding site and a $K_{i}$ (valine) of $6 \times 10^{-5} \mathrm{M}$ (Fig. $6 b$ ).
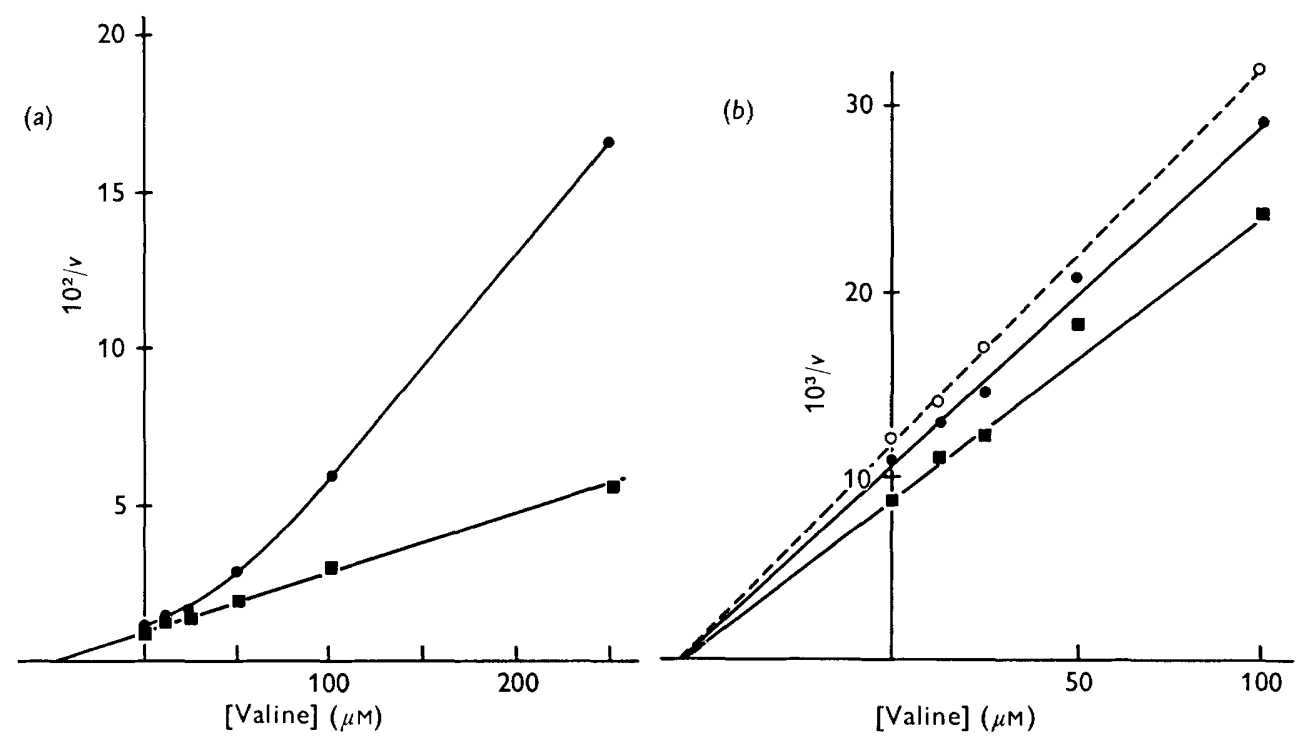

Fig. 6. Reciprocal plots of $1 /$ activity against [valine]. Benzene-treated cells were used. Strain Q 176 (a); high-yielding strain (b). Pyruvate at $5 \mathrm{~mm}(0)$ or $25 \mathrm{~mm}(\square)$ was added. In a third case $(O)$ pyruvate $(25 \mathrm{~mm})$ and isoleucine (IO $\mathrm{mM})$ were added together.

Lineweaver-Burk plots in the presence and absence of isoleucine (tested in the high yielding strain only) also suggested non-competitive inhibition although even at the much higher level of $10 \mathrm{~mm}$, the inhibition was much less than with valine (Fig. $5 b$ ). This inhibition by isoleucine was found to be non-competitive with respect to valine by the method of Webb (1963); when the reciprocals of enzyme activity are plotted against a range of concentrations of valine in the absence and presence of isoleucine the lines cross to the left of the vertical axis (Fig. $6 b$ ).

It should be emphasized that none of the observations reported here could be made in cells prepared in bovine serum albumin + sucrose + phosphate instead of $25 \%(\mathrm{v} / \mathrm{v})$ glycerol. This standard medium for stabilizing enzyme preparations was used for much exploratory work and although no loss of enzyme activity was observed, it was impossible to detect enzyme inhibition. A similar effect has been reported for Saccharomyces cerevisiae (Magee \& de Robichon-Szulmajster, I968). 


\section{DISCUSSION}

This work was initiated to see if the ability to form penicillin was in any way associated with changes in the normal end-product control mechanism exerted by valine. Even in the high yielding strain used for some of this work, end-product control was essentially the same as found in other organisms.

As might be expected for the first enzyme of a sequence, acetohydroxyacid synthetase was inhibited specifically and effectively by very low concentrations of valine. However, in the mutational treatment that has given rise to the high yielding strain, one of the sites for inhibition originally present in Q I76 has been lost, and only the allosteric site, for which valine is a strictly non-competitive inhibitor, remains. This change, associated with the higher level of enzyme activity in the high yielding strain, would effectively ensure that the supply of valine for penicillin synthesis can be readily satisfied, without significantly increasing the pool concentration of valine.

No sign of co-operative interactions between substrate binding sites, typical of many regulating enzymes, was observed, although it is probable that the kinetic experiments could not be carried out at sufficiently low reactant concentrations. Magee \& de Robichon-Szulmajster (I968) similarly failed to observe any such interactions in Saccharomyces cerevisiae, possibly for the same reason.

The inhibition effects of the other amino acids, examined briefly in the high yielding strain, were small. However, when threonine was present with other amino acids the inhibition observed was significantly less than would have been expected, due probably to the use of acetohydroxyacid synthetase for the synthesis of isoleucine as well as valine and thus allowing isoleucine formation to continue when threonine is available. Threonine deaminase is the major site for end-product control by isoleucine in a number of organisms (Umbarger, 1956; de Robichon-Szulmajster \& Magee, I968) but we have shown inhibition of acetohydroxyacid synthetase by isoleucine in Penicillium chrysogenum, although it is more than 300 times less active than valine in this respect. Using a technique detailed by Webb (I963) it was shown that this inhibition is not caused by competition for the valine binding site.

No end-product control by enzyme repression could be detected; in fact the activity of the enzyme produced by cells grown in the presence of valine or all the involved amino acids was at times higher than in their absence (S. A. Goulden \& F. W. Chattaway, unpublished experiments). The explanation of these findings by a more general metabolic response will be the subject of a subsequent communication.

The penicillin producing ability of the high yielding strain is several times greater than that of its parent strain, the end-product control exerted by one of the required amino acids, valine, differing only in degree. It allows the formation of more valine than in the wild type through having lost a valine binding site. The similar existence of end-product control, by lysine, over the production of $\alpha$-aminoadipate, another component involved in the synthesis of penicillin, has been demonstrated in a lysine requiring mutant of the high yielding strain (Goulden \& Chattaway, I968).

The authors would like to express their gratitude to Glaxo Laboratories, Limited, and to the Biochemistry Department, University of Leeds, for the opportunity to carry out the research as an exercise in industrial and academic research collaboration. The authors thank Mr R. Beardsworth for his technical assistance throughout this work. 


\section{REFERENCES}

ARMSTRONG, F. B. \& WAGNER, R. P. (1963). Repression of the valine-isoleucine pathway in Salmonella. Proc. natn. Acad. Sci. U.S.A. 49, 628.

Freundlich, M. R., Burns, R. O. \& Umbarger, H. E. (I962). Control of isoleucine, valine and leucine biosynthesis (I) Multivalent repression. Proc. natn. Acad. Sci. U.S.A. 48, 1804.

Goulden, S. A. \& Chattaway, F. W. (1968). Lysine control of $\alpha$-Aminoadipate and penicillin synthesis in Penicillium chrysogenum. Biochem. J. r10, 55 P-56P.

JUNI, E. (I96I). Evidence for a two-site mechanism for decarboxylation of $\alpha$-keto acids by $\alpha$-carboxylase. J. biol. Chem. 236, 2302.

Krampitz, L. O. (1948). Synthesis of acetyllactic acid. Archs. Biochem. Biophys. I7, 8I.

LeAvitT, R. \& UMBARGER, H. E. (I96I). Isoleucine and valine metabolism in Escherichia coli.J. biol. Chem. 236, 2486.

MAgee, P. T. \& DE Robichon-Szulmajster, H. (1968). Regulation of isoleucine-valine biosynthesis in Saccharomyces cerevisiae. 3. Properties and regulation of the activity of acetohydroxyacid synthetase. Eur. J. Biochem. 3, 507.

DE Robichon-Szulmajster, H. \& MAGeE, P. T. (1968). The regulation of isoleucine-valine biosynthesis in Saccharomyces cerevisiae. I. Threonine deaminase. Eur. J. Biochem. 3, 492.

Segel, I. H. \& Johnson, M. J. (196I). Accumulation of intracellular inorganic sulphate by Penicillium chrysogenum. J. Bact. 8I, $9 \mathrm{I}$.

TARDREW, P. L. \& Johnson, M. J. (1958). Sulphate utilisation by penicillin-producing mutants of Penicillium chrysogenum. J. Bact. 76, 400.

UMBARGER, H. E. (1956). Evidence for a negative feedback mechanism in the biosynthesis of isoleucine. Science, N.Y. I23, 848.

UMBaRger, H. E. \& BRown, B. (I957). Threonine deamination in Escherichia coli. II. Evidence for two L-threonine deaminases. J. Bact. 73, 105.

Umbarger, H. E. \& Davis, B. D. (I962). Pathways of amino acid biosynthesis. In The Bacteria. Ed. by I. C. Gunsalus and R. Y. Stanier, vol. 3, p. I67. New York: Academic Press.

WeBb, J. L. (1963). In Enzyme and Metabolic Inhibitors, vol. I, p. 489. New York and London: Academic Press.

WeSterfeld, W. W. (1945). A colorimetric determination of blood acetoin. J. biol. Chem. 16r, 495. 